\title{
Novi zahvati gradnje u povijesnoj jezgri i okolici Trogira
}

Radić, Danka

Source / Izvornik: Institucije povijesti umjetnosti : zbornik 4. kongresa hrvatskih povjesničara umjetnosti, 2019, 205 - 214

Conference paper / Rad u zborniku

Publication status / Verzija rada: Published version / Objavljena verzija rada (izdavačev PDF)

https://doi.org/10.31664/z4khpu.28

Permanent link / Trajna poveznica: https://urn.nsk.hr/urn:nbn:hr:254:265032

Rights / Prava: Attribution 4.0 International/Imenovanje 4.0 međunarodna

Download date / Datum preuzimanja: 2023-04-26

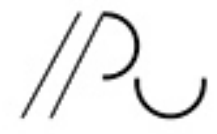

INSIITUTR ZA POVIJEST UMJETNOST
Repository / Repozitorij:

PODEST - Institute of Art History Repository

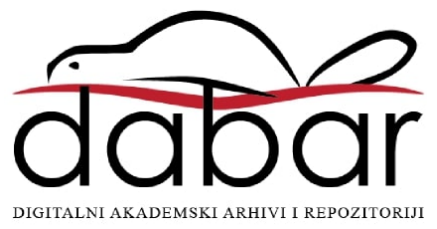




\section{Novi zahvati gradnje u povijesnoj jezgri i okolici Trogira}

\section{Uvod}

Zbog svoje kulturne i povijesne vrijednosti, povijesna jezgra grada Trogira uurštena je u UNESCO-ou Popis sujetske baštine 6. prosinca 1997. godine kao dobro pod okriljem Konvencije o zaštiti sujetske kulturne i prirodne baštine.

Povijesna jezgra Trogira na otočiću, okružena morem, već je zaštićena kao spomenik nulte kategorije sujetske urijednosti, a također je upisana u popis od stotinu mediteranskih naselja od posebnog značenja pri UNEP-ovu centru u Marseillesu.

Urbanistička i arhitektonska cjelina Trogira sačuvala je sve do danas elemente srednjovjekoune strukture uturđenoga grada, karakterističan raspored ulica $i$ trgova, reprezentativne vjerske $i$ sujetoune gradevine te zbijeno tkivo stambenih zgrada. Trogir je $u$ prvom redu iznimno vrijedna cjelina koja je s mnoštvom suojih poruka, umjetničkih, kulturnih i povijesnih, jedno od najurednijih kulturnih dobara u Hrvatskoj.

Uvrštenje u Popis sujetske baštine dragocjena je promidžba i izvanredno priznanje. Ono nas potiče na dodatnu brigu za naše spomenike kulture i na još veći trud kako bismo baštinu sačuvali u njezinu izvornom obliku i kako bi povijest grada ostala vidljiva pri suakom koraku po njegovim ulicama.

Stoga se Grad Trogir svečano obvezuje da će štititi, održavati i promicati svoju povijesnu jezgru, koju treba očuvati na dobrobit cijelog čovječanstua i prenijeti budućim naraštajima. Pritom će se rukovoditi načelima Konvencije o sujetskoj baštini te se pouzdaje da $u$ tome može računati s pomoći UNESCO-a i zajednice gradova sujetske baštine.

Tako piše u deklaraciji koja je donesena u Trogiru, I7. lipnja I998. na svečanoj sjednici Gradskoga vijeća prigodom uručenja povelje o upisu povijesne jezgre Trogira u Listu svjetske baštine UNESCO-a. ${ }^{1}$ Ta je registracija pridonijela popularizaciji grada Trogira. Bio je to impuls s kojim su neke stvari na polju zaštite, rehabilitacije i revitalizacije grada Trogira krenule nabolje. Trudom djelatnika Ministarstva kulture, odnosno

\section{Danka Radić}

Hrvatski pomorski muzej, Split drdankaradic@gmail.com

https://orcid.org/oooo-ooo2-946o-9o9X
I DANKA RADIĆ, Povijesna jezgra grada Trogira upisana u Popis svjetske baštine. Gradska jezgra Trogira-Svjetska baština (Unesco), u: Radovan, 2 (I998.), I6I-I65 
Konzervatorskog odjela u Splitu, započet je milenijski projekt obnove trogirske kulturne baštine. ${ }^{2}$ No konzervatorska zaštita zaustavila se tek na zahvatima na pojedinačnim spomenicima i umjetninama, uglavnom sakralnim, i to po najvišim metodološkim, stručnim i inim standardima, dok se zaboravlja grad kao jedinstveni organizam koji traži zaštitu i rehabilitaciju; relativno se malo čini na rehabilitiranju povijesne jezgre kao spomeničke cjeline. Unatoč upozorenjima o potrebi arhitektonskog snimanja povijesne jezgre grada Trogira još od 1976. godine ${ }^{3}$ ni nakon gotovo dvadeset godina od upisa povijesne jezgre Trogira u UNESCO-ov registar (I997.) ne postoje arhitektonske i konzervatorske podloge bez kojih nema ni sustavnih urbanističkih projekata koji bi ponudili koncept zaštite i rehabilitacije povijesne jezgre. To je i razlog zbog kojeg nema sustavnijih i snažnijih ulaganja u zaštitu, ni bilo kakvih drugih djelovanja u unapređenju i održavanju života u povijesnoj jezgri grada Trogira. No valja istaknuti da je malo koja dalmatinska povijesna jezgra dobila revitalizacijski plan. Većina ih je ostala izvan domašaja planske urbanističke regulative, gomilajući tako strukturne i infrastrukturne probleme. ${ }^{4}$ Egzaktna dokumentarizacija i inventarizacija povijesne jezgre grada Trogira, koju bi trebalo pod hitno izraditi, preduvjet je racionalnog gospodarenja, pa tako i sustavnog planiranja i zaštite urbanističkog naslijeđa grada Trogira. ${ }^{5}$

\section{Novi zahvati u povijesnoj jezgri grada Trogira}

Devastacije, bespravne gradnje, odnosno nelegalne građevinske intervencije $u$ povijesnoj jezgri Trogira još nagrđuju i uništavaju grad kao jedinstvenu cjelinu. Sveudilj i naveliko gradi se bez dozvole; dižu se čitavi katovi od bloketa ili pak od betona. Uništava se krovni pokrov od kupa kanalica na mnogim kućama i zamjenjuje betonskim terasama (sl. I, 2, 2a, 3). Probijaju se mnogobrojni otvori za prozore i vrata, i to bez kamenih okvira. Drvene vratnice i prozori mijenjaju se onima od plastike i aluminija (sl. 4). Uništava se i pločnik. Onaj pred sjevernim gradskim vratima, uz blagoslov konzervatora, zamijenjen je novim kamenim pločama. Recentno su betonirani posljednji vrtovi i dvorišta. Život u gradu postaje sve teži, ako ne i nemoguć; ugostiteljske radnje zagađuju bukom; uzurpiraju se javni prostori, trgovi i ulice. ${ }^{6}$ Ekonomija se svela na samo jednu djelatnost-na turizam, koji ima i negativne efekte na okoliš.
2 DANKA RADIĆ, Zaštita spomenika u Trogiru tijekom XX. stoljeća, u: Zbornik I. kongresa hruatskih poujesničara umjetnosti, (ur.) Milan Pelc, Zagreb, 2004., 429; ista, Degradacija spomenika i ambijenata u Trogiru prema stanju zabilježenom 2002. godine, u: Radovan, 3 (2005.), I32-I33.

3 Ivo Babić bezbroj je puta naglašavao da je za revitalizaciju spomenika najvažnija izrada arhitektonskih snimaka, no nije naišao na razumijevanje konzervatora, koji su se pravdali manjkom kadra i nedostatkom sredstava. Zapravo, radilo se o neadekvatnoj intelektualnoj aparaturi u pristupu tako složenu fenomenu kao što je to grad Trogir. Godine I976. priredio je za Skupštinu općine Trogir Promemoriju o potrebi revitalizacije spomeničke baštine. Iste godine organizirao je akciju SOS za baštinu. IVO BABIĆ, Problematika zaštite povijesne jezgre Trogira, u: Arhitektura 3I, I6o-I6I (I977.), 6-I2; isti, Prostor i njegova kriza, u: Vartal, 2, I-2 (I993.), 5I-62; isti, O akciji sos za Trogir, tri desetljeća poslije, u: Ivi Maroeviću baštinici u spomen, (ur.) Marko Špikić, Zagreb, 2009., 2OI.

4 IVO BABIĆ, Povijesne jezgre dalmatinskih gradova i njihova sudbina, u: Zbornik znanstvenog skupa Prelogova baština danas: $u$ povodu devedesete obljetnice rođenja Milana Preloga, (ur.) Katarina HorvatLevaj, Zagreb, 20I3., II4-I29.

5 DANKA RADIĆ (bilj. 2, 2005.), I3I-I33.

6 DANKA RADIĆ (bilj. 2, 2005) ), I3I-I33.
Slika I

Primjer devastacije: betonska terasa nad dvorištem foto: Maja Maljković

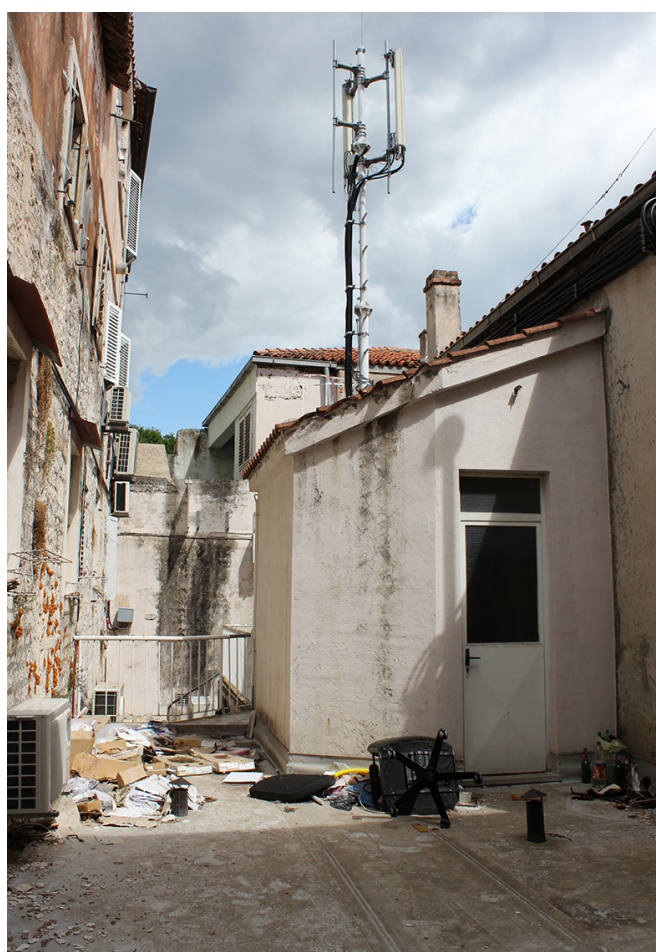



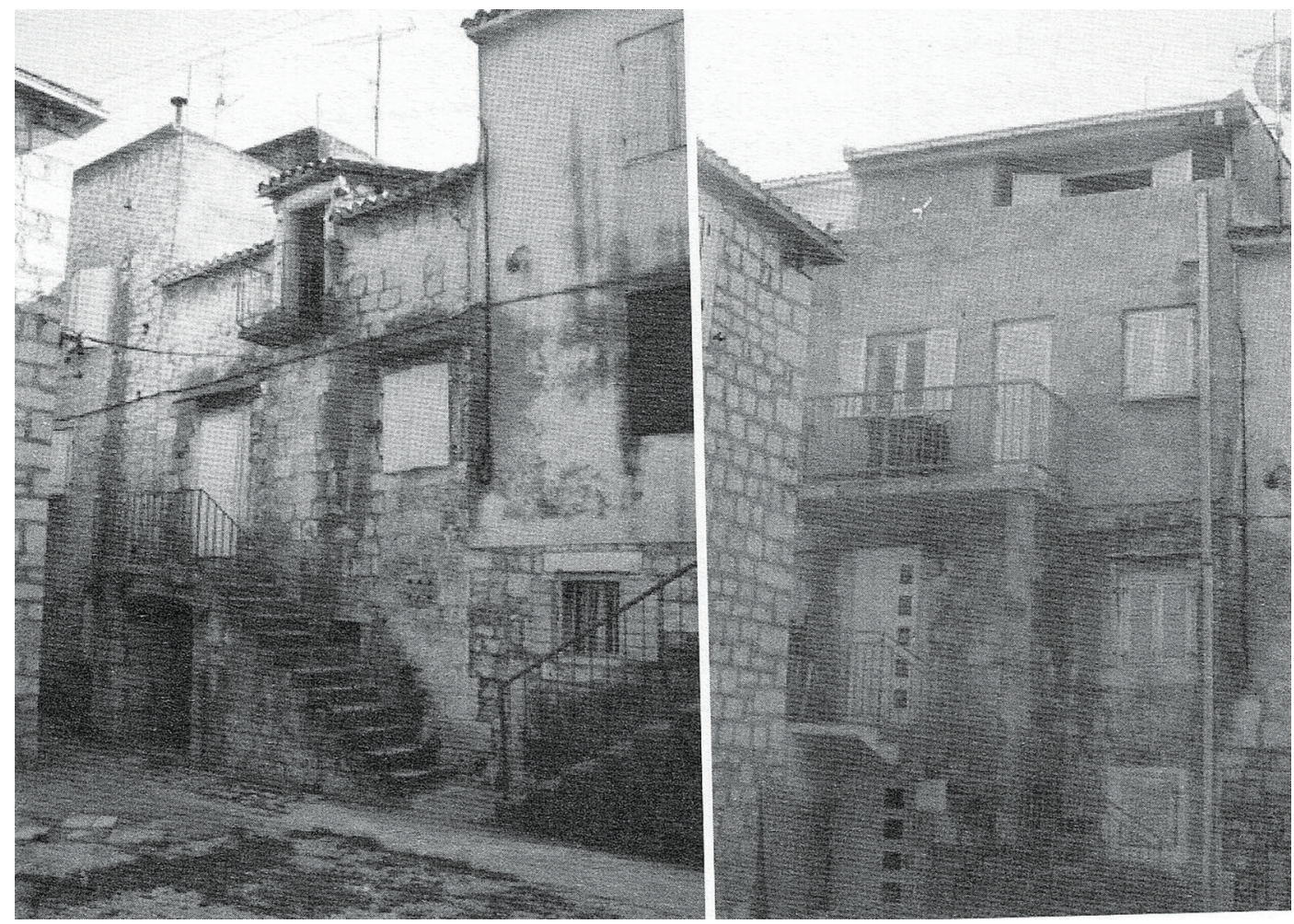

Slika 2

Primjer devastacije: stanje prije i nakon preinaka

Preuzeto iz: Ivo Babić, O akciji sos

za Trogir, tri desetljeća poslije, u: Ivi

Maroeviću baštinici u spomen, (ur. ) Ž.

Vujić, M. Špikić, Zagreb, 2009.

Slika 2a

Primjer devastacije: stanje nakon

posljednjih preinaka

foto: Danka Radić

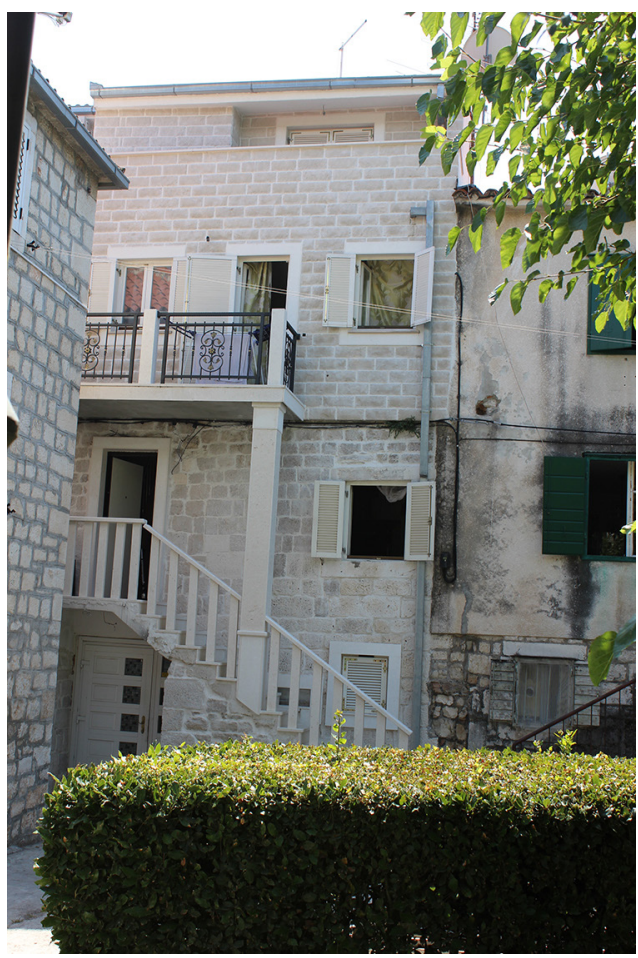



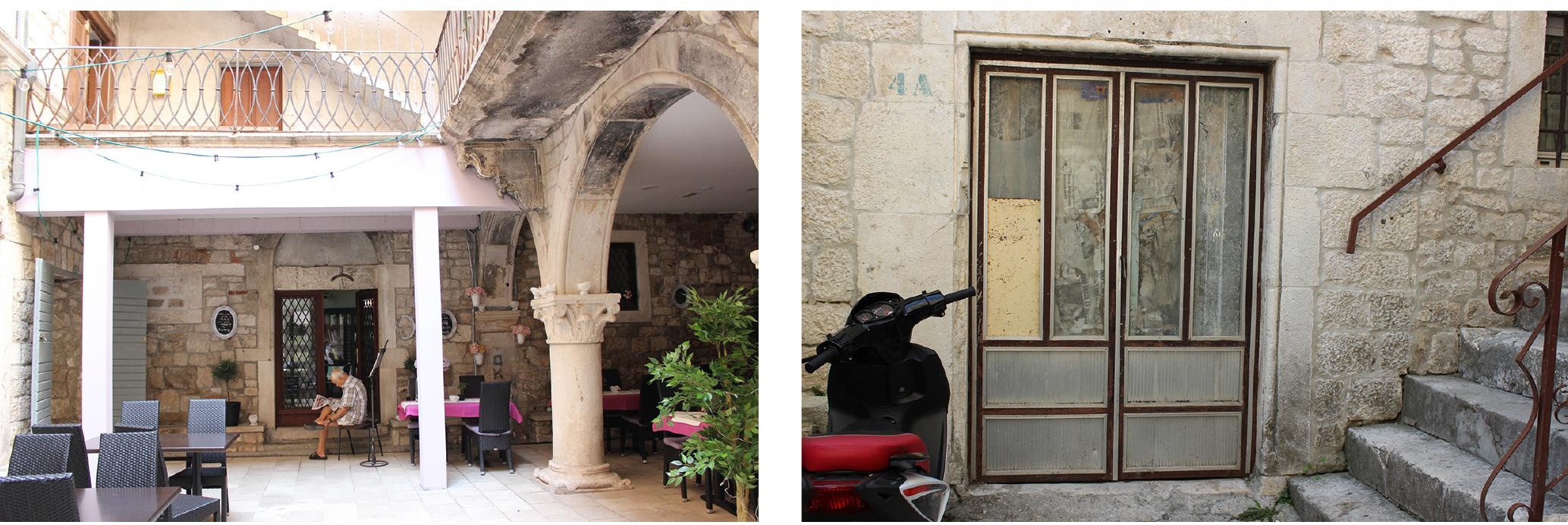

I recentno postavljeni spomenici poput odljeva kipa Krista s anđelima na Cimatoriju pred zapadnim ulazom u trogirsku katedralu ${ }^{7}$ te spomen-obilježje stradalima u bombardiranju Trogira 23. veljače i944. godine ${ }^{8}$ degradirali su povijesnu i ambijentalnu vrijednost povijesne jezgre grada Trogira te posvadili trogirsku, ali i širu hrvatsku javnost. Njihovo postavljanje pratio je niz nesporazuma proizašlih iz nedostatka suradnje službe zaštite i civilnog društva - primjerice, nisu ishodovane sve potrebne dozvole. Zrelost društva vrlo se dobro može mjeriti njegovim odnosom prema spomeničkoj baštini. Ako našu sredinu i naše vrijeme podvrgnemo takvu testu, usprkos naporima mnogobrojnih specijaliziranih službi, uočit ćemo veliko nerazumijevanje za čuvanje i zaštitu spomeničkog blaga. No nesporazumi često počinju već u krugu onih koji su izravno kao stručnjaci angažirani u zaštiti spomenika.

Stanovnici povijesne jezgre grada Trogira slabije financijske moći ne mogu udovoljiti zahtjevima konzervatora pri obnavljanju svojih kuća (iznimno visoka cijena konzervatorskih studija, projektne dokumentacije i izvedbenih radova ovlaštenih tvrtki za radove u povijesnoj jezgri), pa su prisiljeni napuštati jezgru i prodavati kuće, uglavnom strancima. Zato je velik broj kuća opustio; mnoge su na rasprodaji. Depopulacija, napuštanje i propadanje povijesne jezgre sve je očitije; predlaže se da se škola i sve komunalne službe izmjeste iz povijesne jezgre (da se Kneževa palača i zgrada škole prenamjene u hotel), kao i premještanje nogometnog igrališta na kopno. Gotovo 40.000 $\mathrm{m}^{2}$ i više stotina stanova unutar trogirske povijesne jezgre danas je izvan funkcije (prazne su palače rodova Cega, Andreis, Berislavić, Stafileo....). Grade se novi stanovi na kopnu i na otoku Čiovu, umjesto da se rehabilitiraju postojeći. Izumiranje života u starim gradskim jezgrama te prepad imućnijih privatnih i javnih korisnika na atraktivnu povijesnu arhitekturu i lokaciju bolno je iskustvo s kojim se, osim Trogira, suočavaju i ostali dalmatinski gradovi poput Dubrovnika. ${ }^{9}$
Slika 3

Primjer devastacije: Palača Lucio foto: D. Radić

Slika 4

Primjer devastacije: aluminijske vratnice

foto: D. Radic
7 IVO BABIĆ - IVANA PRIJATELJ PAVIČIĆ, Trogirski Krist i neprimjeren „spomenik” na neprimjerenom mjestu, u: Anali Galerije Antuna Augustinčića, 32-35 (2OI5.), 47-62.

8 DANKA RADIĆ, Nesporazumi o postavljanju spomen-obilježja stradalima u bombardiranju Trogira 23. veljače I944. godine. Nedostatak suradnje službe zaštite i civilnoga društva, u: Anali Galerije Antuna Augustinčića, 32-35 (20I5.), 439-449.

9 MAJA NODARI, Hoće li Dubrovnik ostati živi grad (spomenik)?, u: Zbornik II. kongresa hrvatskih povjesničara umjetnosti, (ur.) Irena Kraševac, Zagreb, 20o6., $65-73$. 
Povijesna jezgra grada Trogira nema revitalizacijski plan. Urbanističko-konzervatorski projekt stare jezgre, započet prije tridesetak godina, nije završen zbog nesporazuma konzervatora i urbanista. Osim snimke grada u tlocrtu u mjerilu I : 200 koju je izradio I956. godine Savezni zavod za zaštitu spomenika kulture u Beogradu, te snimke pojedinih objekata u mjerilu I : 50 (katedrala, palače Cippico, Garagnin i Paiton), ${ }^{10}$ ne postoji kompletna arhitektonska dokumentacija, pa tako ni urbanistički plan ni urbanističko-konzervatorska studija za povijesnu jezgru grada Trogira. ${ }^{11}$ Najnovije urbanističko planiranje zaobilazi povijesnu jezgru grada Trogira kao sivu zonu i ne nudi ni jedan mikrozahvat koji bi mogao bljesnuti u zapuštenom trogirskom prostoru. Projekt talijanskog investitora koji je bio načinjen r993. godine bez javnog natječaja za novi hotel s pripadnom marinom na zapadnom rubu povijesne jezgre Trogira, za koji se zalagala tadašnja vlast Trogira, srećom nije realiziran zahvaljujući apelima stručnjaka. Takav projekt bitno bi izmijenio izgled Trogira. ${ }^{12}$ Valja, međutim, napomenuti da u Pasikama imamo čitav jedan gradski kvart-onaj koji je ostao gotovo u istom stanju u kakvu je bio I944. nakon bombardiranja - koji vapi za cjelovitim urbanističkim rješenjem koje može vratiti dobro i kvalitetno življenje u jezgri te riješiti niz stambenih problema. No uvijek je lakše graditi oko povijesne jezgre negoli prilagoditi se postojećemu u jezgri. Stoga se novije urbanističko planiranje svodi tek na prostor izvan povijesne jezgre.

\section{Novi zahvati u okolici povijesne jezgre grada Trogira}

Kaos je sve očigledniji i u okolnom prostoru. Malo je poznato da Trogir zamalo nije ušao na Listu svjetske baštine UNESCO-a isključivo zbog stanja oko povijesne jezgre. ${ }^{13}$ Nova, uglavnom nekontrolirana, izgradnja oko grada nema urbanih obilježja. Unatoč formalnome urbanističkom planiranju, ona sve više izmiče kontroli te je efektivno izvan domašaja planske urbanističke regulative. Prekrajaju se urbanistički planovi prema nalozima politički utjecajnih pojedinaca i klanova. Izgradnja se prisvajanjem morskog dna i dalje širi. Obalne linije kopna i otoka Čiova dodatno se degradiraju i nagrđuju betoniranjem i nasipavanjem; nasipavanjima i betoniranjem sasvim je deformiran i produžen poluotok Cumbrijan „nakićen” lukobranima za jahte. Recentno je na njemu rekonstruirana i svečano otvorena luka nautičkog turizma Servisni centar Trogir. Stambena izgradnja na vrhu Balana, kao i ona oko samostana i crkve sv. Ante na Dridu, sasvim je degradirala okolni prostor povijesne jezgre. $^{14}$

I na kopnenoj strani u blizini Segeta na obali su izgrađeni vezovi koji sa zapada zaklanjaju pogled na urbanu plastiku Trogira. Zahvat izgradnje luke-pristaništa za trajekte planiran je u neposrednoj blizini granice s Općinom Seget (sl. 5, 5a). Na Solinama bi se uredio turistički prihvatni centar za sve veći broj turista koji pristižu u Trogir, a na koje gradski prostori nisu spremni. Planira se i premještanje autobusnog kolodvora
Io Snimanje palača inicirao je Ivo Babić.

II Miroslav Katić, pročelnik Konzervatorskog odjela u Trogiru, na međunarodnom seminaru Revitalizacija povijesnih jezgri-institucionalni okvir i primjeri iz prakse, održanom 20. i 2I. studenoga 20I4. u Trogiru, najavio je početak, odnosno skori nastavak arhitektonskog snimanja povijesne jezgre grada Trogira.

I2 IVO BABIĆ, Pomak prema crnom. Kronike i polemike, Split-Zagreb, 2005., I36-I4I.

I3 http://www.matica.hr/vijenac/ı6o/Sjaj\%2oi\%20 bijeda\%2onaše\%2obaštine/ (posjećeno I6. siječnja 20I7.).

I4 DANKA RADIĆ, Neki primjeri suvremene devastacije zapadnog, trogirskog dijela otoka Čiova, u: Zbornik 3. kongresa hrvatskih povjesničara umjetnosti, (ur.) Andrej Žmegač, Zagreb, 20I3., 59.

Slika 5 Soline, Trogir foto: Ivo Pervan

Slika 5a Projekt luke-pristaništa za trajekte Preuzeto: http://www.luckauprava-sdz.hr/projekti/ novo-doba-za-drvenike

Slika 6

Parkiralište u parku-šumi

Soline

foto: D. Radić

Slika 7

Ambijent pred ulazom $u$

povijesnu jezgru grada Trogira

foto: D. Radic
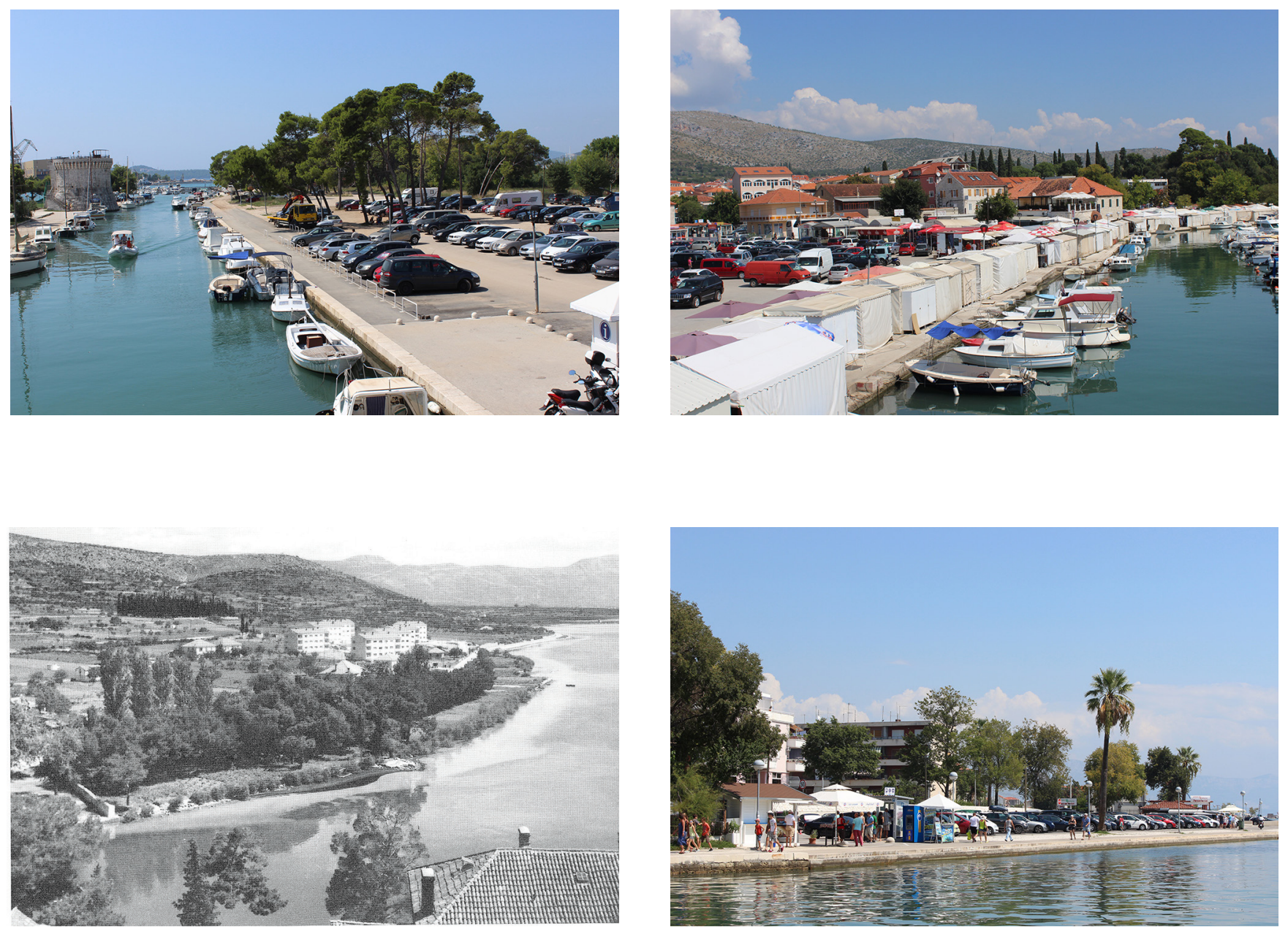

Slika 8

Park Slade-Šilović (prije

Casotti), stanje prije preinaka

fototeka Muzeja grada Trogira

Slika 9

Park Slade-Šilović (prije Casotti), današnje stanje foto: D. Radic 
istočnije na nasipu, na kojem će se podignuti i nova crkva. Uništen je i perivoj Slade-Šilović (nekoć Casotti, sl. 8); asfaltiran je i pretvoren u parkiralište (sl. 9), a planira se i izgradnja hotela. Jedan je od velikih komunalnih zahvata i uređenje šetnice na istočnom ulazu u Trogir.

Najnovijim Prijedlogom urbanističkog plana uređenja naselja Travarica-zapad (predstavljen u ožujku 20I5.) predviđena je stambeno poslovna izgradnja na predjelu parka šume Soline, ${ }^{15}$ čiji su se močvarni plićaci stoljećima koristili za solane. Šuma je posađena na mjestu nekadašnjih močvara početkom 2o. stoljeća kako bi se time spriječilo širenje malarije. Dakle, riječ je o prostoru koji ima svoju povijest i identitet. Grad Trogir gledan s mora doima se poput skulpture koje je zelena zona Solina sastavni dio. Gradovi, kao i skulpture, doživljavaju se jedino u kontekstu svojeg prirodnog okvira, pa bi ga kao takva trebalo i sačuvati. ${ }^{16}$ Prijedlog urbanističkog plana uređenja naselja Travarica-zapad izrađen je bez suradnje i konzultacija s građanima i građanskim udrugama. U širem prostoru nalazi se motel Trogir, koji je projektirao poznati hrvatski arhitekt Ivan Vitić. Sam je motel zbog svojih urbanističkih vrijednosti zaštićen kao spomenik moderne arhitekture. ${ }^{17}$ Gusta stambeno-poslovna izgradnja predviđena tim prijedlogom urbanističkog plana sasvim bi uništila jedinu preostalu zajedničku zelenu zonu, park-šumu Soline, koju bi trebalo obnoviti odnosno hortikulturno urediti. Napominjem da je slika grada s istočne strane već uništena devastacijom spomenuta Šilovićeva parka. Što se tiče parkinga koji se sve više širi i park-šumom Soline-iz tog je razloga recentno posječen dio borove šume (sl. 6)-već odavno sam predlagala zapadno od mosta, na mjestu današnjeg parkinga, izgradnju podzemnih garaža s podmorskim tunelom preko jarka foše, u kojem bi se smjestili dućani-kiosci koji danas pred ulazom u povijesnu jezgru pružaju ružnu sliku grada-ambijent orijentalne čaršije koji nije svojstven dalmatinskom gradu (sl. 7). Financiranje podmorskog tunela moglo bi se olakšati kupnjom prostora za dućane. Bila bi to moguća varijanta primjerena za grad Trogir, koji je pod zaštitom UNESCO-a, o čemu bi trebalo otvoriti široke rasprave u kojima bi sudjelovalo građanstvo, civilne udruge, nadležne i stručne institucije te stručnjaci, posebno iz službe zaštite prirode i kulture. Valja napomenuti da projekt zgrade na parkingu (garaže s poslovnim prostorima), koji je zagovarala prijašnja vlast u Trogiru, zbog veličine nije bio odobren rješenjem Konzervatorskog odjela Ministarstva kulture u Trogiru. Spomenuti prostorno-urbanistički plan za uređenje naselja Travarica-zapad predviđa premještanje autobusnog kolodvora zapadno, umjesto istočno od mosta, te izgradnju škole.

Prijedlogom urbanističkog plana uređenja naselja Travarica-istok (predstavljen u lipnju 20I5.) predviđena je također turističko-stambena izgradnja u okolici novog mosta kopno - otok Čiovo, čija je izgradnja u tijeku. Novim turističkim zonama koje su predviđene novim prijedlozima prostorno-urbanističkih planova za Travaricu-zapad i Travaricu-istok trajno će se narušiti integritet i autentičnost kulturno-povijesne cjeline grada Trogira.
I5 Zadnji je Prostorni plan uređenja grada Trogira donesen 6. travnja 2006. godine. Zamijenio je postojeći iz I979., dopunjen I988. godine. Vidi: JOŠKO BELAMARIĆ Recenzija Prostornog plana uređenja grada Trogira, u: Radovan, 2 (I998.), I55-I56; STANKO GEIĆ, Povodom prijedloga prostornog plana uređenja grada Trogira, u: Radovan, 3 (I998.), I56-I59. Na temelju novog plana, radi njegove dalje provedbe, predviđena je izrada planova prostornog uređenja užeg obuhvata-detaljnije razine.

I6 Radovan, društvo za zaštitu kulturnih dobara Trogira, pokrenut će postupak zaštite parka Soline kod nadležnih institucija za zaštitu prirode. Ovdje je riječ o urbanoj šumi, a novi Zakon o prostornom uređenju I53/I3 kaže da su jedinice lokalne samouprave dužne „poticati razvitak urbanog šumarstva” (Zakon o šumama)

I7 Upozoravamo da je pokrenut niz akcija revalorizacije tog arhitektonsko-pejzažnog kompleksa. Vidi: https://slobodneveze.wordpress.com/motel-trogir/ (posjećeno 7. siječnja 20I7). Motel Trogir: nije uvijek budućnost ono što dolazi / it is not the future that always comes after, (ur.) Nataša Bodrožič, Saša Šimpraga, Zagreb-Eindhoven, 2016., 7-17. 


\section{Novi most kopno-otok Čiovo}

Generalnim urbanističkim planom Trogira i Segeta Donjeg iz I992. godine bila je predložena gradnja mosta s kopna prema otoku Čiovu kako bi se rasteretila jedina prometnica za otok Čiovo, koja se proteže uz istočni obod povijesne jezgre, neposredno uz apside trogirske katedrale. Konačni Prijedlog prostornog plana uređenja grada Trogira predvidio je povezivanje otoka Čiova s kopnom novim prometnim koridorom. Prometna studija Urbanističkog instituta Hrvatske ponudila je dva osnovna građevinsko-tehnička rješenja, odnosno nekoliko varijanata mostova i podmorski tunel. Društvo za zaštitu kulturnih dobara Trogira u prvom broju svoga časopisa Radovan, tematski posvećenu gradnji mosta preko jarka foše, dotiče se pitanja prometnog povezivanja kopna s otokom Čiovom i donosi članke i studije naših stručnjaka Igora Krstulovića, Jure Radnića i Zorana Botića. ${ }^{18}$ Iz mogućih tehničkih rješenja prijelaza kanala i zahtjeva kojima treba udovoljiti, te izbora lokacija koje se predlažu, razvidno je da je gradnja tunela pod morem jedina varijanta koja je primjerena gradu Trogiru i da ima velike prednosti pred mostom te je društvo Radovan predložilo da u tom smjeru treba tražiti prikladna rješenja. Zbog toga je neobično da konačni Prijedlog prostornog plana uređenja grada Trogira od svibnja 2002. godine u vezi s prometnom povezanosti otoka Čiova s kopnom uopće ne spominje podmorski tunel kao moguće rješenje. Valja istaknuti da je većina gradova isprepletena mrežom podzemnih tunela za ceste, željeznice, metroe (tuneli ispod rijeka i mora-Loire, Seine, Temze, La Manchea, Bakarskog zaljeva). U doba kad Venecija, koja je sva isprepletena morskim kanalima, izrađuje planove o podzemnom prometnom povezivanju metroom, u trogirskom slučaju nema ni spomena tunela. Bilo koje rješenje prijelaza mostom kopno-otok Čiovo, bio to niski ili pak visoki most, ne daje zadovoljavajuće rješenje za prostornu situaciju Trogira (sl. Io).

U ambijentu kakav je zapadni dio Kaštelanskog zaljeva, u kojem se nalazi predio Pantan, ihtiološko-ornitološki rezervat, bilo kakav most sa svojom dispozicijom i veličinom nametnut će se okolini i na taj način degradirati kvalitetu krajolika i vizure na sam grad Trogir. Linije mosta narušit će obrise Trogira gledana prema zapadu. Na istoku pak most će sjeći sliku krajolika s Kozjakom i Mosorom u pozadini. Zapravo, jedan od razloga osnutka grada Trogira upravo je morski put; grad je naime smješten na samu ulazu u Kaštelanski zaljev, a taj prometni pravac ima duga tisućljeća tradicije. Most će onemogućiti slobodan prolaz plovila, njihov je broj već sada znatan (nautički turizam), a očekuje se i porast s obzirom na važnost i atraktivnost povijesne jezgre grada Trogira kao svjetske kulturne baštine UNESCO-a. S obzirom na preopterećenost cestovne veze Trogir-Split predviđam u budućnosti veće povezivanje morem kroz Kaštelanski zaljev, posebice ljeti. Tada nastaju velike prometne gužve, prometni čepovi, tako da avionom iz splitske luke možete stići do bilo kojeg odredišta prije negoli cestom od otoka Čiova do Trogira i Splita. Vožnja brodicama-vaporetima iz Splita do Trogira i obrnuto, uz razgledanje
I8 JURE RADNIĆ-ZORAN BOTIĆ, Nova cestovna veza kopno-otok Čiovo, u: Radovan, I (I997.), 25-34.

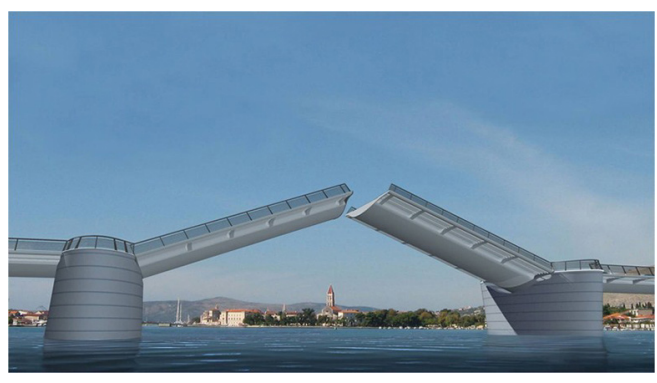

Slika Io

Most kopno-otok Čiovo tijekom izgradnje

foto: Hrvatske ceste. Preuzeto: https://www.tportal.hr/biznis/ clanak/splitsko-poduzece-zaceste-i-strabag-gradit-ce-mostakopno-otok-ciovo-20I7IоII 
Kaštela s mora, za turiste bi svakako bilo atraktivnija negoli vožnja autobusom po kaštelanskoj magistrali uz vizure okolnog urbanističkog i prostornog kaosa. Uz takve nove turističke ponude i gospodarstvo bi moglo profitirati. Primjerice, za realizaciju tih potreba trogirsko brodogradilište moglo bi proizvoditi manja plovila umjesto brodskih giganata. Bili bi to novi impulsi, dodatni izazovi i za mlade trogirske brodograditelje i brodare, koji bi od Trogira mogli načiniti malu Veneciju, a od Kaštelanskog zaljeva hrvatski Lago Maggiore.

Gradnjom tunela mogao se riješiti i problem buke, zagađivanja, ali i ometanja slobodnoga prolaza morem te prijelaza svih energetskih instalacija i kolektora odvodnog sustava Kaštela-Trogir kroz Čiovo (ekološki Kaštelanski zaljev). I pojedini konzervatori i stručnjaci zalagali su se za ideju o gradnji podmorskog tunela. ${ }^{19}$ Ušteda do koje se navodno dolazi izgradnjom mosta umjesto tunela, jer je održavanje mosta jeftinije od održavanja tunela, trajno će onemogućiti Trogir da vrati jedan od elementarnih atributa svoga povijesnoga lika... A Trogir zaslužuje da se o njemu ne razmišlja u pojednostavnjenjima, usputno, po ugovorenu zadatku. Svi navedeni razlozi, kulturno-povijesni, gospodarski, prometni, turistički i nautički, bili su dovoljni da se odluči za povezivanje kopna s otokom Čiovom tunelom, kao jedinom varijantom primjerenom Trogiru. Grad opet po tko zna koji put improvizira, iznalazi privremena rješenja. No nova rješenja morala su biti u skladu s mjerilima novoga tisućljeća. Napominjemo da je već započela izgradnja mosta kopno-otok Čiovo, i to prema projektu glavnog projektanta Jure Radića, direktora IGH, ${ }^{20}$ koji je za taj projekt dobio nagradu grada Trogira za 2008. godinu. ${ }^{21}$

\section{Zaključak}

Uočena je slaba koordinacija konzervatorskih i komunalnih službi. Prilikom važnijih zahvata u prostoru i jedni i drugi trebali bi konzultirati stručnjake i, dakako, civilno društvo. No u tom smislu nema dobre suradnje, što je u suprotnosti sa suvremenom teorijom i praksom zaštite spomenika, koja nastoji da se što širi krugovi društva uključe u zaštitu baštine. Voluntarističko ponašanje i odlučivanje u uskim krugovima interesnih skupina, daleko od očiju javnosti, u suprotnosti je s idealima i praksom civilnog društva. Nedostatak suradnje službe zaštite i civilnog društva uobičajena je praksa u Trogiru. Nažalost, kako se to već često ističe, „to je atmosfera naše svakodnevnice, bolesnog društva koje je u fazi civilizacijske regresije". Razlog je i u tome što se na civilno društvo i njegovu funkciju „psa čuvara” (watch dog) gleda kao na opoziciju aktualnoj vlasti te se u javnosti percipira kao negativna. No evidentno je da civilno društvo, građani koji se aktivno i slobodno „upliću” u sve sfere društvenog djelovanja, igraju sve veću ulogu, osobito u zemljama mlade demokracije kao što je naša. Sve su glasnije građanske inicijative, među kojima su istaknuti intelektualci i stručnjaci raznih profila, koji stalno upozoravaju na nedostatak suradnje službe zaštite i civilnog društva. ${ }^{22}$
I9 JOŠKO BELAMARIĆ, Novi most ili podmorski tunel pokraj Trogira?, u: Vijenac, Iı8 (I7. svibnja 200I.), 5; DANKA RADIĆ, Hoćemo tunel a ne most!, Čovjek i prostor, Još jednom o podmorskom povezivanju Trogira i Čiova, u: Slobodna Dalmacija, Forum, I8. prosinca 2002.; ista, Još jednom za podmorski tunel? Aktualiziranje gradnje mosta-podmorskog tunela između Čiova i Trogira, u: Vijenac, 254 (27. studenoga 2003.), I5. BORIS OREŠIĆ, Apel za Trogir u zadnji čas, glas razuma s Građevinskog fakulteta. Splitski profesori protiv Jure Radića, u: Globus, 903 (2008.), I62-I65

20 JURE RADIĆ, ZLATKO ŠAVOR, NIJAZ MUJKANOVIĆ Most kopno-otok Čiovo u Trogiru, u: Građevinar, 6I, 9 (2009.), $863^{-870 .}$

2I Dresden je uklonjen s UNESCO-ova popisa svjetske baštine zbog izgradnje četiri traka mosta preko rijeke Elbe tek nešto više od jedne milje od gradske povijesne jezgre. Hoće li se isto dogoditi i povijesnoj jezgri grada Trogira?!

22 Vidi djelovanje udruga Građanska inicijativa Split (https://www.gist.hr) i dubrovačke Srđ je naš (https:// srdjenas.com). 
No bolja koordinacija konzervatorskih i komunalnih službi, koje bi prilikom važnijih zahvata u prostoru konzultirale stručnjake i, naravno, civilno društvo, mogla bi pridonijeti poboljšanju zaštite i revitalizacije grada. U tom smislu trebalo bi potaknuti predstavnike lokalnih vlasti i stručnjake da uz pomoć civilnog društva konceptualiziraju i konkretiziraju razvojne pravce trogirske kulturno-povijesne sredine; nužna je politička volja da se razvoj sustavno planira. Nova urbana politika morala bi odabrati funkcionalni i društveno-ekonomski pristup, uključujući različite partnere te poštujući prirodni izgrađeni okoliš. Dakako, urbana povijest rezimirana u „povijesnom planu"-prostorno-planskom dokumentu u kojem će precizno biti zabilježen razvoj grada te izrađene konzervatorske podloge kao identifikacijski dokument svakoga pojedinog objekta, preduvjet je sustavnog planiranja.

\section{(ㄷ) (1)}

Novi zahvati gradnje u povijesnoj jezgri i okolici Trogira/Danka Radić / CC BY / 4.O

DoI: https://doi.org/Io.31664/z4khpu.28 